\title{
Strength Degradation of Glass Fiber Reinforced Polymer Bars Subjected to Reversed Cyclic Load
}

\author{
J. Y. Lee, ${ }^{\text {a,1 }}$ K. H. Kim, ${ }^{\text {S }}$ S. W. Kim, ${ }^{\text {b }}$ and M. Chang ${ }^{\mathrm{c}}$
}

a Department of Civil, Architectural, and Environmental System Engineering, Sungkyunkwan University, Suwon, Republic of Korea

${ }^{\mathrm{b}}$ Department of Architectural Engineering, Kongju National University, Kongju, Republic of Korea

c EPC Architectural \& Structural Engineering Team, Doosan Heavy Industries \& Construction, Republic of Korea

1 jylee@skku.ac.kr

\section{УДК 539.4}

\section{Разупрочнение полимерных стержней, армированных стекловолокном, при циклической переменной нагрузке}

\author{
Д. Ю. Лй, ${ }^{\mathrm{a}, 1}$ К. Х. Ким ${ }^{6}$, С. В. Ким ${ }^{\sigma}$, М. Чанг \\ а Факультет гражданского строительства, архитектурного проектирования и проектирования \\ систем окружающей среды, Университет Сонгюнгван, Сувон, Республика Корея \\ ${ }^{\sigma}$ Факультет архитектурного проектирования, Национальный университет Конджу, Конджу, \\ Республика Корея \\ в Проектно-техническая группа ЕПС, Дусан Хеви Индастрис \& Констракшн, Республика
Корея
}

Полимеры, армированные стекловолокном, имеют повышенную коррозионную стойкость, поэтому используются в строительстве в качестве альтернативы стальной арматуре. Арматурный стержень, армированный стекловолокном, обладает высоким пределом прочности при растяжении, средним модулем упругости и упругим поведением вплоть до разрушения. При расчете данного стержня необходимо использовать нетрадиционный подход, поскольку предполагается, что связь на границе раздела между арматурным стержнем, армированным стекловолокном, и бетоном отличается от таковой для традиционных стальных стержней, так как параметры, оказывающие влияние на прочностную характеристику, имеют разные значения. Представлены результаты экспериментальных и аналитических исследований по оченке прочности связи полимерных стержней, армированных стекловолокном, при монотонной или циклической переменной нагрузке. Для экспериментальных исследований использовали 30 образиов. Установлено, что значения прочности при сдвиге по поверхности раздела для полимерных стержней, армированных стекловолокном, отличаются от таковых для стальных стержней. Прочесс разупрочнения полимерных стержней, армированных стекловолокном, при ичклической переменной нагрузке более жесткий, чем при монотонной нагруз$\kappa e$.

Ключевые слова: полимер, армированный стекловолокном, прочность связи, схемы нагрузки, разупрочнение.

Introduction. Over the last a few decades, there has been significant growth in the use of fiber reinforced polymer (FRP) composites as construction materials in the civil engineering community due to their favorable properties such as high-strength-to-weight ratio, good corrosion resistance, labor cost reductions, and easy on-site handling. One of 
the main reasons for considering of FRP bars for concrete reinforcement is that steel bars can corrode in concrete subjected to harsh environments, resulting in a loss of strength and structural integrity. Concrete exposed to chlorides through marine or deicing salts is particularly prone to corrosion of reinforcing steel.

In order to use FRP bars as a construction material, adequate bond behavior of the FRP bars in concrete is necessary not only to ensure an adequate level of safety, by allowing the two materials (FRP bars and concrete) to work together, but also to control the structural behavior, by providing an adequate level to deformability. Bond strength is influenced mainly by the roughness of the rebar surface condition, the concrete mixing, the cover of concrete, and the types of loading. Although the bond performance between FRP bars and the surrounding concrete has been established and clearly addressed in various design codes [1-3], direct application of the codes to FRP bars would be imprudent act because the interfacial bond behavior of FRP bars to concrete is expected to vary from that of conventional steel bars. The variation arises from the fact that FRP bars have different parameters that influence bond performance from those of conventional steel bars, such as surface condition of the bars, modulus of elasticity, shear stiffness, and tensile strength. Hence, there is a need to establish clear understanding of the interfacial bond behavior of FRP bars in concrete.

Many studies on the effects of surface conditions, casting positions, bar size, and concrete strength and the design of analytical models have been performed to examine the bond behavior of steel bars [4-6]. On the other hand, few test results are currently available regarding the interfacial bond behavior of FRP bars. Cosenza et al. [7] studied bond mechanisms and the influence of type of fiber and external surface condition. According to the experimental results, sand-coated FRP rebars showed better bond resistance than FRP smooth rods. Achillides [8], Shima et al. [9], Okelo and Yuan [10], and Lee et al. [11] tested the bond strength of FRP bars under monotonic loading and noted that the bond strength of the FRP bar appears to be influenced by the interlaminar shear strength just below the resin rich surface layer of the bar. Achillides [8] has reported that the FRP bond strength can only increase with concrete compressive strength up to $50 \mathrm{MPa}$. On the other hand, Okelo and Yuan [10] suggested that the bond strength of FRP showed a linear relationship with the square root of the concrete compressive strength. Most research on the bond performance of the FRP rebars so far were focused on the elucidation of the bond failure mechanisms of FRP rebars subjected to monotonic load. However, detailed investigations available on the interfacial bond behavior of FRP bars under cyclic load have been relatively limited. This paper presents the results of an experimental study on the interfacial strength of glass fiber reinforced polymer (GFRP) bars subjected to reversed cyclic load. The experimental program consisted of testing 30 concrete cubes. Two main parameters were considered in the experimental investigation: the loading patterns and the types of rebars (steel, sand coating GFRP, and helical wrapping GFRP).

\section{Test Program.}

Materials. The used reinforcing bars were two types of GFRP bars and one type of steel bar supplied by international manufacturers. The GFRP bars are made of continuous longitudinal glass fibers glued together with a thermosetting resin. The nominal diameter of the bars was $12.7 \mathrm{~mm}(\# 4)$. The surface of the GFRP bars was treated to improve bond by sand coating (SC-GFRP, by Pultrall Inc.) and helical wrapping with sand coating (HW-GFRP, by Hughes Brothers Inc.). The fiber volume fraction and density of all GFRP bars were $70 \%$ and approximately $2 \mathrm{~g} / \mathrm{cm}^{3}$, respectively. The fracture strength of GFRP bars ranged from $617 \mathrm{MPa}$ to $690 \mathrm{MPa}$, and the elastic modulus was $200 \mathrm{GPa}$ for the steel and 40.8 GPa to $42.0 \mathrm{GPa}$ for the GFRP bars. All of the GFRP bars followed a linear stress-strain behavior up to failure. The concrete cylinder tests were carried out according to ASTM C39, Standard Test Method for Compressive Strength of Cylindrical Concrete Specimens. The average concrete strength of each specimen at the time of parent concrete 
cylinder test was $35.0 \mathrm{MPa}$. The nominal coarse aggregate size was limited to $13.0 \mathrm{~mm}$ to ease the placement of concrete inside the small formwork.

Specimens and Test Configuration. The $190.5 \times 152.4 \times 102 \mathrm{~mm}$ cube specimens were prepared. Each specimen consisted of a concrete cube with a single rebar embedded vertically along a central axis. The specimens were prepared based on the ASTM Standard C234 [12] and CSA S806-02 standard [13]. The concrete was cast with the rebar in the vertical position inside the steel formwork that was prepared in accordance with ASTM Standard C234. The bonded length of the rebar was set to $63.5 \mathrm{~mm}$, five times the diameter of the rebar. In order to minimize the effect of stress from the loading plate, the bar was sheathed with soft PVC tube to prevent bonding between the bar and concrete on the loaded and free end sides (Fig. 1). Concrete was placed in four layers of approximately equal thickness, and each layer was rodded 25 times with $16 \mathrm{~mm}$ diameter tamping rod. After molding, the specimens were initially cured by covering them with plastic sheet, which prevented moisture loss for $24 \mathrm{~h}$. Immediately after the removal of the molds, specimens were cured in accordance with ASTM Standard C 511 [14] until the time of test. During this curing period, they were sprayed with water twice a day to maintain moisture on the surfaces at all times. Two nominally identical specimens were prepared for each specimen type as shown in Table 1.

$\mathrm{T}$ a b 1 e 1

Test Specimens

\begin{tabular}{||c|c|c|c|c|c|c||}
\hline \multirow{2}{*}{ Load patterns } & \multicolumn{6}{c||}{ Rebars } \\
\cline { 2 - 8 } & \multicolumn{2}{|c|}{ Steel } & \multicolumn{2}{c||}{ GFRP-SC } & \multicolumn{2}{c||}{ GFRP-HW } \\
\cline { 2 - 7 } & 1 & 2 & 1 & 2 & 1 & 2 \\
\hline Monotonic load & MA1 & MA2 & MB1 & MB2 & MC1 & MC2 \\
\hline Cyclic load 1 & L1A1 & L1A2 & L1B1 & L1B2 & L1C1 & L1C2 \\
\hline Cyclic load 2 & L2A1 & L2A2 & L2B1 & L2B2 & L2C1 & L2C2 \\
\hline Cyclic load 3 & L3A1 & L3A2 & L3B1 & L3B2 & L3C1 & L3C2 \\
\hline Cyclic load 4 & L4A1 & L4A2 & L4B1 & L4B2 & L4C1 & L4C2 \\
\hline
\end{tabular}
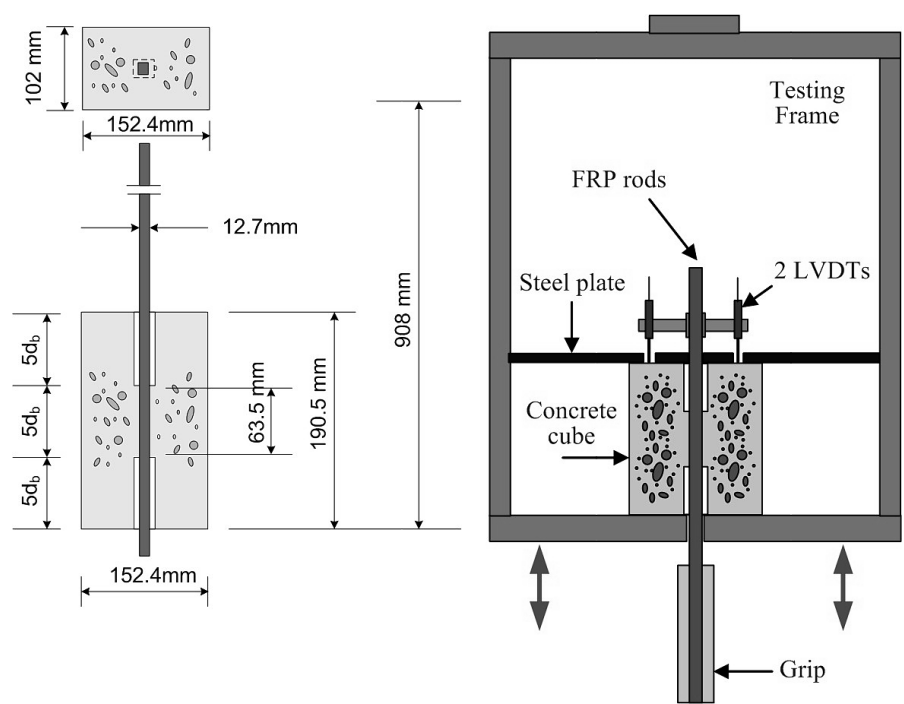

Fig. 1. Test specimens and setup. 
The pullout tests were performed by using a UTM with a capacity of $1,000 \mathrm{kN}$. Load was applied to the rebar at a rate of about $20,000 \mathrm{~N} / \mathrm{min}$. The specimen was mounted on the testing machine such that the face of the cube with long end of the bar was in contact with the bearing block assembly. A spherically seated bearing block was manufactured to transfer the reaction from the block to the weighting table of the testing machine without exerting transverse load on the bar. The projecting rebar was placed through the bearing block assembly, and the bar end was gripped for tension by the jaws, with round wedges, of the testing machine as shown in Fig. 1.

The load was measured with the electronic load cell of the machine. The slips of the rebar relative to concrete at the loaded end and at the free end were measured with three linear displacement transducers (LVDTs). The readings of the applied load and the corresponding LVDTs were recorded automatically through a data logger at specified load intervals.

Five load patterns [15], including one monotonic load and four different reversed cyclic load patterns, were chosen for the test to examine the effect of reversed cyclic loads, as shown in Fig. 2.
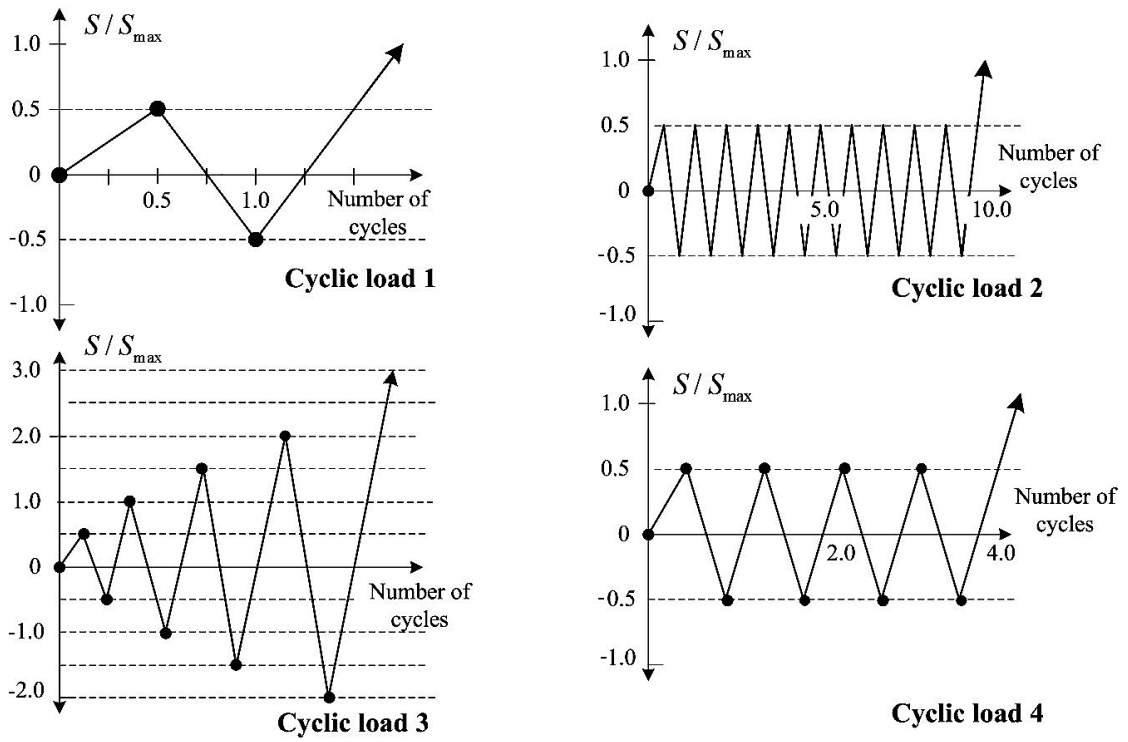

Cyclic load 4

Fig. 2. Load patterns.

Monotonic load: for a monotonic load, the pull-out load was simply applied at a constant rate, until either a steady residual behavior or bond failure was observed.

Reversed cyclic load 1: the reversed cyclic load 1 condition was similar to the monotonic load, except that the load was unloaded once when the slip value reached $S_{m} / 2$, where $S_{m}$ is the slip value corresponding to the maximum applied load under the monotonic load, before application of the monotonic load was resumed.

Reversed cyclic load 2: a reversed cyclic load 2 was applied, under which the rebar was pulled at a constant rate, but with 10 reversed cyclic loads at the slip value of $S_{m} / 2$.

Reversed cyclic load 3: a reversed cyclic load 3 was applied, where the rebar was pulled at a constant rate as shown in Fig. 2.

Reversed cyclic load 4: a reversed cyclic load 4 was applied, under which the rebar was pulled at a constant rate, but with 4 reversed cyclic loads at the slip value of $S_{m} / 2$.

The number of load cycles was chosen to observe the differences in bond degradation between GFRP and steel rebars while most interfacial damage is expected to take place. 


\section{Test Results.}

Monotonic Loading. The bond behavior of three types of rebars in concrete subjected to monotonic and cyclic loadings was observed from the experimental tests. All of the specimens failed by pullout of the rebars. None of specimens showed the failure at the anchorage, the rupture of the rebar, and the splitting of the enclosing concrete.

Figure 3 shows the bond stress-free end slip curves obtained from a pullout test of steel rebar subjected to monotonic load. The curve is divided into three stages as follows:

Stage I (adhesion area): for low bond-stress values, adhesion between the rebar and concrete prevail and little slip occurs. However, highly bond stress increases with little change in slip.

Stage II (from slip to bond strength): adhesion between the rebar and concrete degrades but mechanical interlocking engages as slip increases resulting in higher bond stress. The slope of bond-slip curve at Stage II is lower than that at Stage I.

Stage III (after bond strength): bond stress of steel bars gradually decreases as slip increases.
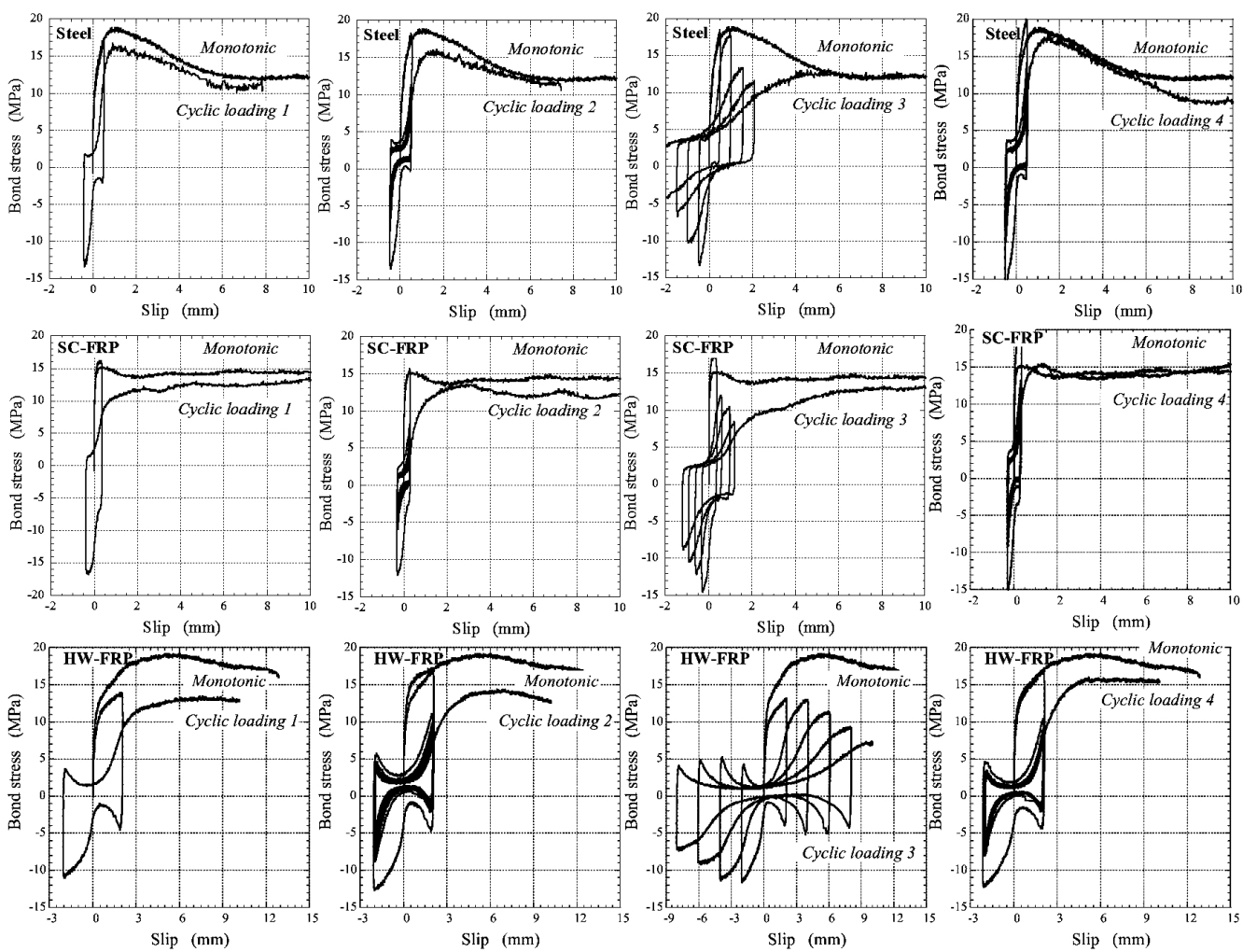

Fig. 3. Bond stress vs. slip curves of test specimens subjected to monotonic and cyclic loads.

The observed bond behavior of the steel bar was similar to that obtained from the pull-out tests by Eligehausen et al. [16].

The test results of SC-FRP bars subjected to monotonic load are plotted in Fig. 3. The bond stress-slip curves of SC-FRP bars also showed the bond behavior associated with three stages, as observed in the steel bars. However, the bond strength of SC-FRP bar was smaller than that of steel bars, and the bond stress of the SC-FRP bar reached a peak immediate after a measurable slip was observed. In the descending branch of the curve, the bond stress of SC-GFRP rebar reduced gradually with increasing slip. 
The bond stress versus slip curve of HW-GFRP rebar showed characteristics that are more similar to those of steel than the SC-GFRP, but displayed a greater slip value corresponding to the bond strength than that of the steel. The average slip value corresponding to the maximum bond stress was $5.4 \mathrm{~mm}$, which was $4.4 \mathrm{~mm}$ more than that of the steel. The slope of the curve segment between the end of the adhesive bond and the maximum bond strength for HW-GFRP bar was much lower than that for steel rebar, indicating that breaking of adhesive bond results in more adverse effect on the stiffness of composite reinforced with GFRP than with steel. In the descending branch of the curve, the HW-GFRP exhibited a gradual reduction of bond stress.

Cyclic Loading. The results of the cyclic loading are plotted in Fig. 3. The effects of repeated cyclic loads on the bond stress and slip were compared in this figure. In the case of the steel rebar subjected to reversed cyclic loads, the bond strength showed limited degradation. In particular, those subjected to reversed cyclic load type 1, 2, and 4 showed that the bond strength degradation of steel rebar subjected to reversed cyclic load with less than 10 cycles appeared to be negligible.
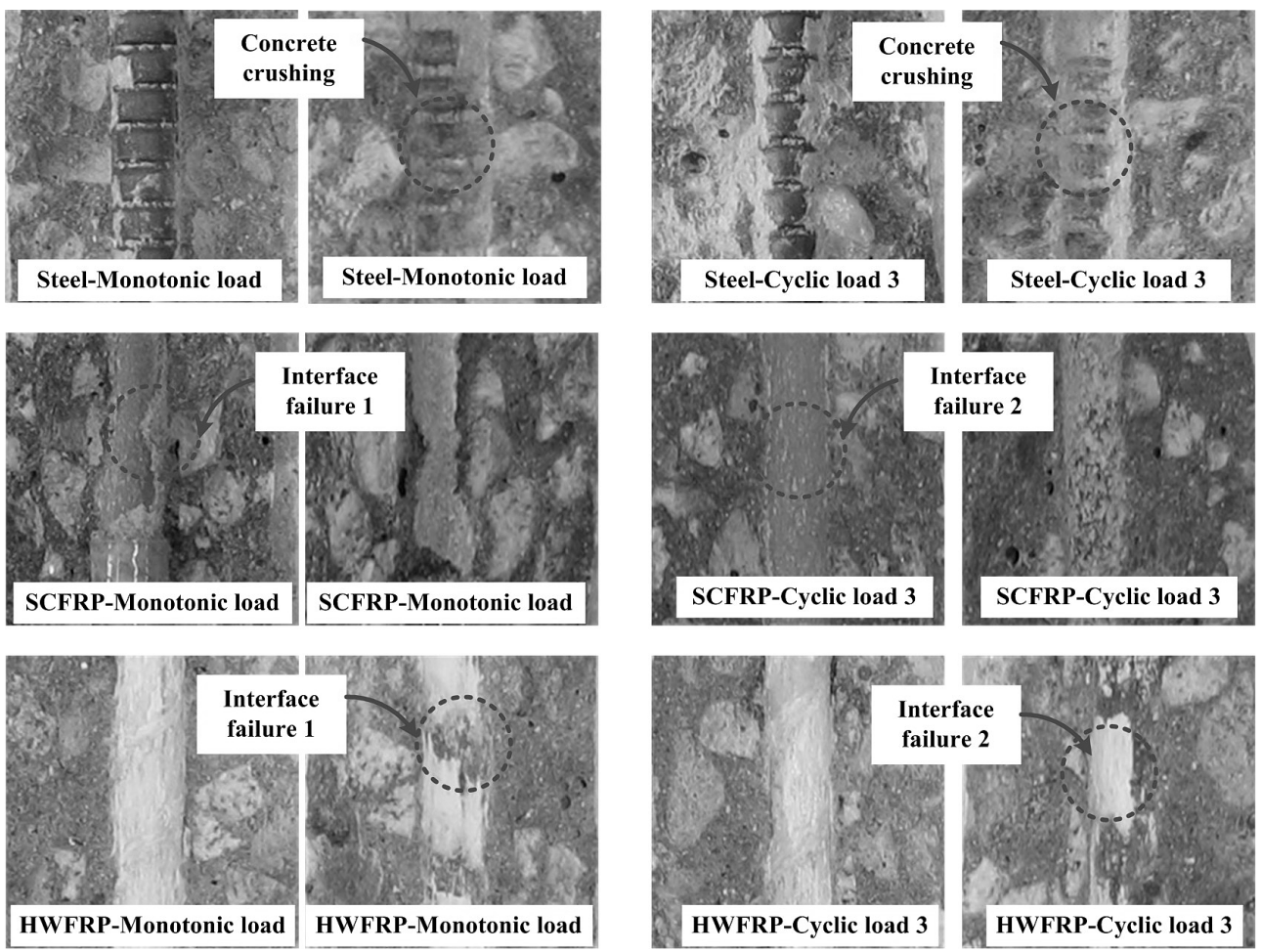

Fig. 4. Bond failure of steel and GFRP bars after test.

Failure Modes. The specimens were split after the tests for a closer investigation of the actual mode of bond failure. Figure 4 shows damages associated with the failures of the specimens. Figure 4 reveals that, in the case of the steel bar, ultimate bond failure occurs due to concrete crushing against the bar deformations. On the other hand, the bond failure of the GFRP bars occurred partly on the surface between concrete and resin (interface failure 1) and partly on the surface between resin and bar fiber due to peeling of the surface layer of the bar (interface failure 2), as shown in Fig. 4. The failure at interface 1 occurs when the shear strength between concrete and resin is smaller than the shear strength between resin and bar fiber, while the failure at interface 2 occurs when the shear strength between resin and bar fiber is smaller than the shear strength between concrete and resin. 
Hence, the bond strength and failure mode of the GFRP bars depends on the relative shear strengths of interface 1 and 2. The photos in Fig. 4 for the SC-GFRP and HW-GFRP bars subjected to monotonic load shows concrete pieces still attached to the bars over the embedment length, while the photos in Fig. 4 for the SC-GFRP and HW-GFRP bars subjected to reversed cyclic load shows none of the concrete pieces attached. The delaminated areas at interface 2 were digitally measured using a graphic software. The ratio of the delaminated area at interface 2 to the total surface area of the SC-GFRP and HW-GFRP bars subjected to reversed cyclic load was much greater than that of SC-GFRP and HW-GFRP bars subjected to monotonic load. Therefore, it may conclude that the number of loading cycle changes the failure mode of GFRP bars from interface 1 to interface 2 .

Conclusions. In this study, experimental investigations were conducted to determine the effects of rebar types and loading patterns on the bond performance of various bars in concrete. The test results indicated that the bond strength degradation of GFRP bars subjected to reversed cyclic load was more severe than that of the steel bars. HW-GFRP bars under reversed cyclic load showed the bond strength degradation of greater than $20.8 \%$. The discrepancy between the bond strength under monotonic loading and the bond strength under repeated loading of HW-GFRP was greater than that of steel bars or SC-GFRP bars. The steel bars subjected to reversed cyclic load were failed by concrete crushing in front of the bar deformations. The bond failure of GFRP, however, occurred partly on the surface between concrete and resin and partly on the surface between resin and bar fiber. The number of loading cycles changed the failure mode of GFRP bars from interface 1 to interface 2. As a result, the strength degradation of GFRP bars under reversed cyclic load was more severe than that of the steel bars or GFRP bars under monotonic load.

Acknowledgments. This research was supported by Basic Science Research Program through the National Research Foundation of Korea (NRF) funded by the Ministry of Education (2013006697).

\section{Резгме}

Полімери, армовані скловолокном, мають підвищену корозійну стійкість, тому використовуються на будівництві як альтернатива стальній арматурі. Арматурний стрижень, армований скловолокном, має високу границю міцності при розтязі, середній модуль пружності і пружну поведінку майже до руйнування. Для розрахунку даного стрижня необхідно використовувати нетрадиційний підхід, оскільки припускається, що зв'язок на границі поділу між арматурним стрижнем, армованим скловолокном, i бетоном відрізняється від такого для традиційних стальних стрижнів, оскільки параметри, що мають вплив на міцнісну характеристику, мають різні значення. Представлено результати експериментальних і аналітичних досліджень щодо оцінки міцності зв'язку полімерних стрижнів, армованих скловолокном, за монотонного або циклічного змінного навантаження. Для експериментальних випробувань використовували 30 зразків. Установлено, що значення міцності при зсуві по поверхні поділу для полімерних стрижнів, армованих скловолокном, відрізняються від таких для стальних. Процес знеміцнення полімерних стрижнів, армованих скловолокном, під час циклічного змінного навантаження більш жорсткий, аніж за монотонного навантаження.

1. ACI Committee 318-11. Building Code Requirements for Reinforced Concrete and Commentary (ACT 318-11/ACI 318R-1), American Concrete Institute, Detroit (2011).

2. Comittee European de Normalisation (CEN). Eurocode 2: Design of Concrete Structures. Part 1 - General Rules and Rules for Buildings, prEN 1992-1 (2002). 
3. CSA Committee A23.3-04. Design of Concrete Structures for Buildings, CAV3A23.3-04, Canadian Standards Association, Canada (2004).

4. T. J. Looney, M. Arezoumandi, J. Volz, and J. J. Myers, "An experimental study on bond strength of reinforcing steel in self-consolidating concrete," Int. J. Concr. Struct. Mater., 6, No. 3, 187-197 (2012).

5. R. Hameed, A. Turatsinze, F. Duprat, and A. Sellier, "Bond stress-slip behaviour of steel reinforcing bar embedded in hybrid fiber reinforced concrete," KSCE J. Civil Eng., 17, No. 7, 1700-1707 (2013).

6. B. H. Oh and S. H. Kim, "Realistic models for local bond stress-slip of reinforced concrete under repeated loading," ASCE J. Struct. Eng., 133, 216-224 (2007).

7. E. Cosenza, G. Manfredi, and R. Realfonzo, "Behavior and modeling of bond of FRP rebars to concrete," J. Compos. Constr., 1, 40-51 (1997).

8. Z. Achillides, Bond Behavior of FRP Bars in Concrete, Thesis, Centre for Cement and Concrete, Dept. of Civil and Structural Engineering, The University of Sheffield (1998).

9. H. Shima, T. Suga, and M. Honma, "Local bond stress-slip relationship of continuous fibre reinforcing materials obtained by pull bond test with long embedment," Trans. Japan Concr. Inst., 15, 297-304 (1993).

10. R. Okelo and R. L.Yuan, "Bond strength of fiber reinforced polymer rebars in normal strength concrete," J. Compos. Constr., 9, No. 3, 203-213 (2005).

11. J. Y. Lee, T. Y. Kim, T. J. Kim, et al., "Interfacial bond strength of glass fiber reinforced polymer bars in high-strength concrete," Composites Part B: Engineering, 39, 258-270 (2008).

12. ASTM Standard Test Method, Comparing Concrete on the Basis of the Bond Developed with Reinforcing Steel, C 234 (1991).

13. CSA. Design and Construction of Building Components with Fibre-Reinforced Polymers, S806-02, CSA (2002).

14. ASTM Standard Specification for Moist Cabinets. Moist Rooms, and Water Storage Tanks Used in the Testing of Hydraulic Cements and Concretes, C 511-92 (1992).

15. M. Chang, Research on the Bond Behavior of fiber reinforced Polymer Rebars Subjected to Cyclic Loading, M.S. Thesis, Sungkyunkwan University, Suwon (2006).

16. R. Eligehausen, E. P. Popov, and V. V. Bertero, Load Bond Stress-Slip Relationships of Deformed Bars under Generalized Excitations, Report No. UCB/EERC82-83, Earthquake Engineering Research Center, University of California, Berkeley, CA (1983). 